\title{
PENGARUH PEMANGKASAN PUCUK TERHADAP PERTUMBUHAN DAN HASIL TANAMAN MENTIMUN JEPANG (Cucumis sativus L.) DI DATARAN TINGGI LEMBANG
}

\author{
Oleh : \\ Siti Nur Aeni *) \\ Rini Sitawati dan Pasetriyani **)
}

\begin{abstract}
Abstrak
Percobaan yang dilakukan bertujuan untuk mendapatkan jenis pemangkasan yang dapat meningkatkan hasil mentimun jepang. Percobaan dilakukan di bulan April 2018 hingga Juni 2018 di Desa Cibogo kecamatan Lembang Kabupaten Bandung Barat dengan ketinggian tempat 1.250 mdpl. Rancangan yang digunakan adalah Rancangan Acak Kelompok (RAK) dengan enam perlakuan dan empat ulangan sehingga terdapat 24 plot percobaan. Setiap perlakuan terdiri dari 5 tanaman, sehingga jumlah keseluruhannya 120 tanaman. Hasil percbaan menunjukkan terjadinya pengaruh pemangkasan pucuk terhadap hasil tanaman mentimun Jepang.Tanpa pemangkasan pucuk pada batang utama serta pemangkasan pucuk pada seluruh cabang lateral dan pemangkasan pucuk pada batang utama serta pemangkasan pucuk pada lima cabang lateral memberikan hasil yang baik
\end{abstract}

Kata kunci : Mentimun jepang, Pemangkasan pucuk, Batang utama, Cabang lateral.

\begin{abstract}
The experiment was aimed to give kinds of prunning could increase result japan cucumber. The experiments was conducted from April 2018 until Juni 2018 at Cibogo Village Lembang., West Bandung with an altitude of $1.250 \mathrm{~m}$ above sea level. The experiment method used complete randomized design (CRDB) of six treatments and four replications, therefore there are 24 experiment plot. Each treatment consist of 5 plants, so there are 120 plants total. The results showed there was effect of prunning shoots plants result japan cucumber. Without pruning shoots on main stem and pruning shoots on all lateral branch and pruning shoots on main stem and pruning shoots on five lateral branch give good results.
\end{abstract}

Keyword: Japan cucumber, Pruningshoots, Main stem, Lateral branch.

*)Alumni Faperta Universitas Bandung Raya

**) Dosen Tetap Faperta Universitas Bandung Raya

Pengaruh Pemangkasan Pucuk terhadap

Pertumbuhan dan Hasil Tanaman

SITI NUR AENI, RINI SITAWATI dan PASETRIYANI

Mentimun Jepang (Cucumis sativus L.) di

Dataran Tinggi Lembang 


\section{PENDAHULUAN}

Tanaman mentimun (Cucumis sartivus L.) berasal dari benua Asia, tepatnya Asia Utara meski sebagian ahli menduga berasal dari Asia Selatan. Para ahli tanaman memastikan daerah asal mentimun adalah India, tepatnya di lereng gunung Himalaya. Mentimun banyak disukai oleh masyarakat, dikonsumsi sebagai lalapan, sebagai pelengkap makanan, bahan kosmetika, atau sebagai bahan baku obat-obatan, selain itu buah mentimun dapat digunakan sebagai bahan baku industri minuman, permen dan parfum (Rukmana, 1994).

Mentimun ditanam di dataran rendah dan dataran tinggi dengan ketinggian tempat 0-1000 m dpl (Yadi S, La Karimuna dan L Sabaruddin 2012). Menurut Rosliani (2013), tanaman mentimun dapat tumbuh dengan baik pada ketinggian tempat $200-800 \mathrm{~m} \mathrm{dpl}$, dan tumbuh dengan keadaan optimum pada daerah yang memiliki ketinggian tempat $400 \mathrm{~m}$ dpl. Namun perlu dicoba membudidayakan mentimun di dataran tinggi dengan ketinggian lebih dari $1000 \mathrm{~m}$ $\mathrm{dpl}$, agar terlihat perbedaannya dengan budidaya mentimun di dataran rendah. Pada dataran tinggi pertumbuhan mentimun didominasi oleh pertumbuhan vegetatif sehingga pembentukan bunga lebih sedikit, hal disebabkan tingkat lama penyinaran kurang dari 12 jam dan curah hujan tinggi akan menggugurkan bunga mentimun, oleh karena itu perlu diadakan pemangkasan bagian vegetatif agar sinar matahari dapat terserap optimal.

Mentimun Jepang disebut juga mentimun Kyuri merupakan mentimun hibrida di Indonesia ditanam hanya sebagai tanaman selingan ( Cahyono, 2003). Bentuknya lebih ramping dan panjang dibandingkan dengan mentimun lokal. Kulitnya berwarna hijau gelap dengan bintik-bintik putih timbul yang membuat permukaan kulitnya tidak rata. Rasa dan tekstur mentimun ini lebih lembut daripada mentimun lokal.
Mentimun jenis ini cocok diolah menjadi campuran salad dan acar.

Menurut Yadi S, La Karimuna dan L Sabaruddin. (2012) mentimun jepang dapat ditanam di dataran rendah sampai dengan dataran tinggi, hal ini menjadi peluang untuk memperluas daerah budidaya mentimun jepang sehingga budidaya mentimun jepang tidak terbatas hanya di dataran rendah saja sehingga jumlah produksi mentimun jepang dapat bertambah.

Berdasarkan data Badan Pusat Statistik (BPS, 2016) produksi mentimun di Indonesia terus menerus menurun dari tahun ke tahun, pada tahun 2012 sampai tahun 2015 berturut-turut 511,525 ton/ha, 491,636 ton/ha, 477,976 ton/ha dan 447,677 ton/ha. Hal ini kemungkinan disebabkan oleh masih kurang intensifnya budidaya mentimun yang dilakukan oleh para petani.

Upaya untuk meningkatkan produksi mentimun di Indonesia harus dilakukan, salah satunya dengan perbaikan teknik budidaya yaitu dengan dilakukannya antara lain teknik pemangkasan yang sesuai/baik. Teknik budidaya untuk meningkatkan produksi mentimun dapat dilakukan dengan cara memanipulasi pertumbuhan, yaitu dengan perlakukan pemangkasan (Dewani, 2000). Pemangkasan dapat dilakukan dengan memotong ujung atau pucuk tanaman yang dinamakan pemangkasan pucuk serta pemangkasan pada cabang lateral. Dengan dilakukannya pemangkasan, diharapkan pertumbuhan tunas dan cabang semakin banyak, sehingga potensi munculnya bunga semakin banyak pula.

Pemangkasan pucuk akan mempengaruhi produksi dan aliran auksin ke tunas tunas lateral. Jumlah auksin pada tanaman yang berlebihan akan terjadi dominansi pucuk yang menghambat pertumbuhan tunas dibawahnya. Hal ini terjadi karena adanya pertumbuhan tunas lateral sehingga percabangan akan semakin banyak dan menaungi antar daun tanaman. Bagian pucuk tanaman 
merupakan jaringan meristem apikal yang merupakan sumber pembentukan auksin. Pada bagian ini aktifitas pembelahan dan pembesaran sel tinggi sekali sehingga dengan adanya pemangkasan dapat merangsang translokasi auksin pada sekitar bagian yang dipotong dan merangsang pembentukan cabang baru. Senyawa perangsang lainnya seperti sukrosa dan senyawa nitrogen disintesa dalam daun kemudian ditranslokasikan ke bagian yang terpotong. Akumulasi tersebut sampai batas tertentu akan merangsang pembentukan cabang baru (Januwati dkk,1996).

Berdasarkan uraian di atas, belum diketahui jenis pemangkasan seperti apa yang dapat meningkatkan produksi mentimun jepang di dataran tinggi, sehingga penelitian mengenai pemangkasan tanaman mentimun jepang yang ditanam di dataran tinggi perlu dilakukan agar didapat informasi mengenai jenis pemangkasan yang tepat untuk meningkatkan produksi mentimun jepang di dataran tinggi.

Berdasarkan uraian di atas dapat diidentifikasi masalah sebagai berikut:

1. Apakah pemangkasan pucuk berpengaruh terhadap pertumbuhan dan hasil tanaman mentimun jepang yang dibudidayakan di dataran tinggi Lembang.

2. Pada bentuk pemangkasan yang bagaimana yang berpengaruh baik terhadap pertumbuhan dan hasil mentimun jepang di dataran tinggi Lembang.

Maksud penelitian ini adalah untuk mengetahui pengaruh pemangkasan pucuk terhadap pertumbuhan dan hasil mentimun jepang di dataran tinggi Lembang.

Tujuan penelitian ini adalah untuk mendapatkan jenis pemangkasan yang berpengaruh baik terhadap pertumbuhan dan hasil mentimun jepang di dataran tinggi Lembang.
Penelitian ini dapat digunakan sebagai bahan informasi dan dapat menambah wawasan bagi peneliti khususnya dan masyarakat umumnya mengenai pemangkasan sebagai salah satu cara untuk meningkatkan hasil mentimun jepang (Cucumis sativus .L) di dataran tinggi Lembang.

\section{METODE PENELITIAN}

\section{Waktu dan Tempat Percobaan}

Percobaan dilaksanakan di dataran tinggi Lembang ( $1.250 \mathrm{~m} \mathrm{dpl}$ ) tepatnya di Desa Cibogo Kecamatan Lembang Kabupaten Bandung barat pada bulan April sampai Juni 2018. Ditinjau dari segi geologis jenis tanah di daerah tersebut merupakan tanah Andisol yang beriklim tipe $\mathrm{B}$, dengan suhu rata-rata harian berkisar antara 19-24\% C, kelembaban udara berkisar 34-90\% dan rata-rata curah hujan $2.207,5 \mathrm{~mm} /$ tahun.

\section{Alat dan Bahan Penelitian}

Bahan - bahan yang digunakan dalam penelitian ini adalah benih mentimun, tanah dan pupuk kandang ayam sebagai media tanam, trey untuk tempat persemaian, polybag .Alat yang digunakan dalam kegiatan penelitian adalah: cangkul, kored, selang dan emrat untuk menyiram, gunting untuk memangkas, timbangan untuk menimbang buah, meteran dan jangka sorong untuk mengukur buah dan alat tulis.

\section{.Metode penelitian}

Metode penelitian yang digunakan adalah metode percobaan, dengan rancangan yang digunakan adalah Rancangan Acak Kelompok (RAK) dengan 6 (enam) perlakuan dan 4 (empat) ulangan. Seluruh plot percobaan ada 24 (dua puluh empat) plot dengan perlakuan sebagai berikut

Pengaruh Pemangkasan Pucuk terhadap

Pertumbuhan dan Hasil Tanaman

SITI NUR AENI, RINI SITAWATI dan PASETRIYANI

Mentimun Jepang (Cucumis sativus L.) di

Dataran Tinggi Lembang 
Tabel 1. Jenis pemangkasan yang digunakan

\begin{tabular}{cl}
\hline Perlakuan & \multicolumn{1}{c}{ Jenis pemangkasan yang digunakan } \\
\hline A & Tanpa pemangkasan \\
B & $\begin{array}{l}\text { Tanpa pemangkasan pucuk pada batang utama dan pemangkasan pucuk seluruh } \\
\text { cabang lateral }\end{array}$ \\
C & $\begin{array}{l}\text { Tanpa pemangkasan pucuk pada batang utama dan pemangkasan pucuk } 3 \text { cabang } \\
\text { lateral }\end{array}$ \\
D & Tanpa pemangkasan pucuk pada batang utama dan pemangkasan pucuk 5 cabang \\
& lateral \\
E & Pemangkasan pucuk pada batang utama dan pemangkasan pucuk 3 cabang lateral \\
F & Pemangkasan pucuk pada batang utama dan pemangkasan pucuk 5 cabang lateral \\
\hline
\end{tabular}

\section{Pelaksanaan Penelitian}

\section{Persiapan media tanam}

Media tanam yang digunakan adalah tanah yang terdapat disekitar kebun yang diambil dari tanah lapisan kedua dengan kedalaman $20-40 \mathrm{~cm}$, tanah lapisan kedua dipilih karena belum banyak terkontaminasi pupuk dan pestisida kimia dibanding dengan lapisan atas atau topsoil. Kemudian tanah dicampur dengan pupuk kandang ayam dengan perbandingan 1: 1 , setelah tercampur rata, kemudian media tanam disterilkan dengan cara pemberian bahan aktif Dazomet 98 $\%$ dengan tujuan agar cendawan, telur serangga, bakteri - bakteri pathogen, mikoplasma akar gada, dan nematoda nematoda pathogen pada tanah mati. Campuran media tanam tersebut kemudian dimasukkan ke dalam polybag yang berukuran 40 × $40 \mathrm{~cm}$ kemudian polybag disusun berdasarkan tata letak percobaan yang sudah dibuat.

\section{Persiapan benih mentimun}

Sebelumnya mentimun dikecambahkan terlebih dahulu dengan cara benih direndam di dalam air hangat selama 2 jam kemudian dibungkus kain dan diletakkan ditempat lembab selama 3 hari 3 malam sampai benih mulai berkecambah, kemudian benih disemai ke dalam trey selama 1 minggu dan ditunggu hingga bibit memiliki 2 buah daun untuk selanjutnya dipindahkan ke tempat penelitian.

\section{Penanaman}

Kegiatan penanaman dilakukan pada sore hari dengan maksud agar waktu bibit untuk beradaptasi dengan lingkungan baru lebih lama dan mengurangi resiko kematian bibit akibat transpirasi yang terlalu tinggi.

Pemeliharaan tanaman meliputi kegiatan pemupukan susulan dengan menggunakan pupuk NPK dengan dosis 2 gr per tanaman yang dilakukan pada saat tanaman berumur 14 HST, 21 HST dan 30 HST. Pada tanaman mentimun diberi ajir untuk menyangga batang tanaman agar tidak menjajar kemana - mana, selain itu pengikatan batang mentimun pada ajir pun perlu dilakukan agar batang menempel pada ajir dan tanaman tumbuh tegak, pengikatan dilakukan setiap 3 hari sekali. Pengendalian hama dan penyakit dilakukan segera bila terdapat gejala serangan dengan menggunakan insektisida dan fungisida.

\section{Aplikasi pemangkasan}

Kegiatan pemangkasan pucuk pada batang utama dilakukan pada umur 35 HST atau jika tanaman sudah memasuki fase pertumbuhan pada ruas ke 16 sedangkan pemangkasan pucuk cabang lateral mulai dilakukan pada umur $30 \mathrm{HST}$ atau pada saat tanaman sudah memiliki cabang lateral dan dilakukan pada cabang lateral sesuai dengan perlakukan yang diberikan.

Pengaruh Pemangkasan Pucuk terhadap 


\section{Pengamatan Utama}

1. Jumlah cabang lateral yang muncul pada setiap perlakuan, diamati sampai tanaman tidak mengeluarkan cabang dimulai pada umur tanaman 30 HST dengan interval 3 hari sekali.

2. Luas daun $\left(\mathrm{cm}^{2}\right)$ yang diukur pada saat tanaman mentimun mencapai fase pertumbuhan vegetatif maksimum

3. atau pada umur sekitar 40 HST dengan menggunakan metode gravimetri.

4. Jumlah buah per tanaman (buah) yang dipanen dari setiap perlakukan, dihitung dari kegiatan panen pertama mulai umur 48 HST sampai panen terakhir yaitu 60 HST dengan interval panen 3 hari sekali.

5. Berat buah per tanaman (gram) yang dipanen dari setiap perlakuan, ditimbang dari kegiatan panen pertama sampai panen terakhir.
6. Berat buah per buah/butir (gram) ditimbang dari kegiatan panen pertama sampai panen terakhir.

7. Panjang buah $(\mathrm{cm})$ dari setiap perlakuan, diukur dari kegiatan panen pertama sampai panen terakhir.

8. Diameter buah (mm) dari setiap perlakuan, diukur dari kegiatan panen pertama sampai panen terakhir.

\section{HASIL DAN PEMBAHASAN}

\section{Pengamatan Utama \\ Jumlah cabang lateral dan luas daun}

Hasil analisis dengan Uji Jarak Berganda Duncan taraf 5\% pada Tabel 2 menunjukkan perlakuan berbagai jenis pemangkasan pucuk memberikan pengaruh terhadap jumlah cabang lateral dan luas daun yang dimiliki tanaman mentimun jepang

Tabel 2. Jumlah cabang lateral yang tumbuh dan luas daun $\left(\mathrm{cm}^{2}\right)$ pada tanaman mentimun jepang pada setiap perlakuan

\begin{tabular}{|c|c|c|c|c|}
\hline \multicolumn{3}{|r|}{ Perlakuan } & $\begin{array}{c}\text { Rata - rata } \\
\text { Jmlh cab. lateral }\end{array}$ & $\begin{array}{c}\text { Rata - rata } \\
\text { Luas daun }\left(\mathrm{cm}^{2}\right)\end{array}$ \\
\hline $\mathrm{A}$ & $=$ & Tanpa pemangkasan pucuk & $6.50 \mathrm{a}$ & $7016.75 \mathrm{~b}$ \\
\hline B & $=$ & $\begin{array}{l}\text { Tanpa pemangkasan pucuk pada batang utama } \\
\text { dan pemangkasan pucuk seluruh cabang lateral }\end{array}$ & $6.25 \mathrm{a}$ & $4816.75 \mathrm{a}$ \\
\hline $\mathrm{C}$ & $=$ & $\begin{array}{l}\text { Tanpa pemangkasan pucuk pada batang utama } \\
\text { dan pemangkasan pucuk } 3 \text { cabang lateral }\end{array}$ & $6.25 \mathrm{a}$ & $5083.25 \mathrm{a}$ \\
\hline $\mathrm{D}$ & $=$ & $\begin{array}{l}\text { Tanpa pemangkasan pucuk pada batang utama } \\
\text { dan pemangkasan pucuk } 5 \text { cabang lateral }\end{array}$ & $6.00 \mathrm{a}$ & $4950.00 \mathrm{a}$ \\
\hline $\mathrm{E}$ & $=$ & $\begin{array}{l}\text { Pemangkasan pucuk pada batang utama dan } \\
\text { pemangkasan pucuk } 3 \text { cabang lateral }\end{array}$ & $9.75 \mathrm{~b}$ & $4510.00 \mathrm{a}$ \\
\hline $\mathrm{F}$ & $=$ & $\begin{array}{l}\text { Pemangkasan pucuk pada batang utama dan } \\
\text { pemangkasan pucuk } 5 \text { cabang lateral }\end{array}$ & $11.25 \mathrm{c}$ & $4375.00 \mathrm{a}$ \\
\hline
\end{tabular}

Keterangan: Angka rata-rata yang ditandai dengan huruf kecil yang sama menunjukkan berbeda tidak nyata menurut Uji Jarak berganda Duncan taraf nyata $5 \%$.

Dari tabel di atas tampak perbedaan yang signifikan antara perlakuan tanpa pemangkasan pucuk pada batang utama dengan perlakuan pemangkasan pucuk pada batang utama. Hal ini disebabkan dengan adanya pemangkasan pucuk pada batang utama mengakibatkan berkurangnya dominansi apikal sehingga produksi auksin yang disintesis pada pucuk akan terhambat bahkan berhenti sehingga jumlah cabang lateral yang tumbuh akan lebih banyak (Dahlia , 2001). Pada perlakuan tanpa pemangkasan pucuk (A) tampak luas daun paling besar dibandingkan dengan perlakuan lainnya. Hal ini disebabkan dengan tidak adanya pemangkasan pucuk pada batang utama maupun pada cabang lateral sehingga semua daun dapat terukur dan tidak ada daun yang terbuang.

Pengaruh Pemangkasan Pucuk terhadap

Pertumbuhan dan Hasil Tanaman

SITI NUR AENI, RINI SITAWATI dan PASETRIYANI

Mentimun Jepang (Cucumis sativus L.) di

Dataran Tinggi Lembang 
Jumlah Buah Per Tanaman, Berat Buah per Tanaman, Berat buah per Butir (gram)

Hasil analisis menunjukkan perlakuan berbagai jenis pemangkasan pucuk memberikan pengaruh terhadap jumlah buah per tanaman, berat buah per tanaman dan berat buah per butir mentimun jepang. Hasil analisis dengan Uji Jarak Berganda Duncan pada taraf 5 $\%$ disajikan pada Tabel 3

Tabel 3. Jumlah buah, berat buah (gr) pertamanan dan berat buah (gr) per butir yang dihasilkan tanaman mentimun jepang pada setiap perlakuan

\begin{tabular}{|c|c|c|c|c|}
\hline & Perlakuan & $\begin{array}{l}\text { Rata - rata } \\
\text { Jmlh Buah }\end{array}$ & $\begin{array}{l}\text { Rata - rata } \\
\text { Berat Buah (gr) } \\
\text { / Tnm }\end{array}$ & $\begin{array}{c}\text { Rata- rata Berat } \\
\text { Buah (gr) / } \\
\text { Butir }\end{array}$ \\
\hline $\mathrm{A}$ & $=$ Tanpa pemangkasan pucuk & $5.00 \mathrm{ab}$ & $194.50 \mathrm{a}$ & $973.75 \mathrm{a}$ \\
\hline $\mathrm{B}$ & $\begin{aligned}= & \text { Tanpa pemangkasan pucuk pada } \\
& \text { batang utama dan pemangkasan } \\
& \text { pucuk seluruh cabang lateral }\end{aligned}$ & $6.25 \mathrm{~b}$ & $246.50 \mathrm{c}$ & $1530.00 \mathrm{c}$ \\
\hline $\mathrm{C}$ & $\begin{aligned}= & \text { Tanpa pemangkasan pucuk pada } \\
& \text { batang utama dan pemangkasan } \\
& \text { pucuk } 3 \text { cabang lateral }\end{aligned}$ & $4.75 \mathrm{a}$ & $211.50 \mathrm{ab}$ & $1005.50 \mathrm{a}$ \\
\hline $\mathrm{D}$ & $\begin{aligned}= & \text { Tanpa pemangkasan pucuk pada } \\
& \text { batang utama dan pemangkasan } \\
& \text { pucuk } 5 \text { cabang lateral }\end{aligned}$ & $6.00 \mathrm{~b}$ & $222.50 \mathrm{ab}$ & $1336.50 \mathrm{bc}$ \\
\hline $\mathrm{E}$ & $\begin{aligned}= & \text { Pemangkasan pucuk pada batang } \\
& \text { utama dan pemangkasan pucuk } 3 \\
& \text { cabang lateral }\end{aligned}$ & $5.50 \mathrm{ab}$ & $221.00 \mathrm{ab}$ & $1195.75 \mathrm{ab}$ \\
\hline $\mathrm{F}$ & $\begin{aligned}= & \text { Pemangkasan pucuk pada batang } \\
& \text { utama dan pemangkasan pucuk } 5 \\
& \text { cabang lateral }\end{aligned}$ & $6.25 \mathrm{~b}$ & $232.50 \mathrm{bc}$ & $1461.75 \mathrm{c}$ \\
\hline
\end{tabular}

Dari data di atas tampak terlihat bahwa semakin banyak pemangkasan pucuk seluruh cabang lateral maka jumlah buah per tanaman makin banyak, sedangkan berat buah per tanaman dan berat buah per butir terlihat paling berat dibandingkan dengan sedikitnya pemangkasan pucuk. Hal ini terjadi karena makin banyak nya pucuk seluruh cabang leteral yang dipangkas ,maka tanaman lebih banyak menyerap sinar matahari untuk fotosintesis sehingga berpengaruh kepada pembentukan buah.

\section{Panjang Buah (cm) dan Diameter Buah (mm)}

Hasil analisis menunjukkan perlakuan berbagai jenis pemangkasan pucuk memberikan pengaruh terhadap panjang buah dan diameter buah mentimun jepang. Hasil analisis dengan Uji Jarak Berganda Duncan pada taraf 5 $\%$ disajikan pada Tabel 4. 
Tabel 4. Panjang buah $(\mathrm{cm})$ dan diameter buah $(\mathrm{mm})$ mentimun jepang pada setiap perlakuan.

\begin{tabular}{|c|c|c|c|}
\hline & Perlakuan & $\begin{array}{c}\text { Rata - rata } \\
\text { Panjang Buah }(\mathrm{cm})\end{array}$ & $\begin{array}{c}\text { Rata - rata } \\
\text { Diameter Buah }(\mathrm{mm})\end{array}$ \\
\hline $\mathrm{A}=$ & Tanpa pemangkasan pucuk & $23.00 \mathrm{a}$ & $22.75 \mathrm{a}$ \\
\hline $\mathrm{B}=$ & $\begin{array}{l}\text { Tanpa pemangkasan pucuk pada } \\
\text { batang utama dan pemangkasan } \\
\text { pucuk seluruh cabang lateral }\end{array}$ & $30.00 \mathrm{c}$ & $40.00 \mathrm{e}$ \\
\hline$C=$ & $\begin{array}{l}\text { Tanpa pemangkasan pucuk pada } \\
\text { batang utama dan pemangkasan } \\
\text { pucuk } 3 \text { cabang lateral }\end{array}$ & $24.75 \mathrm{~b}$ & $34.00 \mathrm{ab}$ \\
\hline $\mathrm{D}=$ & $\begin{array}{l}\text { Tanpa pemangkasan pucuk pada } \\
\text { batang utama dan pemangkasan } \\
\text { pucuk } 5 \text { cabang lateral }\end{array}$ & $27.25 \mathrm{c}$ & $36.00 \mathrm{~cd}$ \\
\hline $\mathrm{E}=$ & $\begin{array}{l}\text { Pemangkasan pucuk pada batang } \\
\text { utama dan pemangkasan pucuk } 3 \\
\text { cabang lateral }\end{array}$ & $25.50 \mathrm{~b}$ & $34.50 \mathrm{bc}$ \\
\hline $\mathrm{F}=$ & $\begin{array}{l}\text { Pemangkasan pucuk pada batang } \\
\text { utama dan pemangkasan pucuk } 5 \\
\text { cabang lateral }\end{array}$ & $27.00 \mathrm{c}$ & $37.50 \mathrm{~d}$ \\
\hline
\end{tabular}

Keterangan: Angka rata-rata yang ditandai dengan huruf kecil yang sama menunjukkan berbeda tidak nyata menurut Uji Jarak berganda Duncan taraf nyata $5 \%$.

Perbedaan yang nyata terlihat pada perlakuan tanpa pemangkasan pucuk (A) yang memiliki panjang buah dan diameter buah yang paling rendah dibanding dengan perlakuan lainnya. Hal ini terjadi karena pada perlakuan tersebut tidak dilakukan pemangkasan pucuk pada batang utama maupun pada cabang lateral sehingga hasil fotosintesis digunakan tanaman untuk pertumbuhan dan perkembangan bagian vegetatif tanaman seperti daun, cabang dan batang sehingga daun semakin banyak dan bertumpuk satu sama lain.

Perlakuan tanpa pemangkasan pucuk pada batang utama dan pemangkasan pucuk seluruh cabang lateral (B) memiliki panjang buah diameter buah yang paling tinggi dibanding dengan perlakuan lainnya. Pada perlakuan B seluruh cabang lateral yang tumbuh diberi perlakuan pemangkasan pucuk sehingga panjang buah yang terbentuk dan memiliki diameter yang lebih besar dari perlakuan lainnya. Hal ini terjadi karena sebagian besar hasil fotosintesis di gunakan tanaman untuk pertumbuhan dan perkembangan buah secara maksimal.

\section{KESIMPULAN DAN SARAN}

\section{Kesimpulan}

Dari hasil penelitian pengaruh pamangkasan pucuk terhadap pertumbuhan dan hasil tanaman mentimun jepang di dataran tinggi Lembang dapat ditarik kesimpulan sebagai berikut:

1. Terdapat pengaruh pemangkasan pucuk yang diaplikasikan pada tanaman mentimun jepang terhadap pertumbuhan dan hasil tanaman mentimun jepang (kyuri).

2. Untuk pertumbuhan, perlakuan pemangkasan pucuk pada batang utama dan pemangkasan pucuk 5 cabang lateral (F) memiliki jumlah cabang lateral yang paling banyak serta perlakuan tanpa pemangkasan pucuk (A) memilki luas daun yang paling tinggi. Sedangkan untuk hasil, perlakuan tanpa pemangkasan pucuk pada batang utama dan pemangkasan pucuk seluruh cabang lateral (B) memberi hasil berat buah per tanaman, berat buah per butir, panjang buah dan diameter buah paling tinggi.

Pengaruh Pemangkasan Pucuk terhadap

Pertumbuhan dan Hasil Tanaman

SITI NUR AENI, RINI SITAWATI dan PASETRIYANI

Mentimun Jepang (Cucumis sativus L.) di

Dataran Tinggi Lembang 


\section{Saran}

Untuk mendapatkan tanaman mentimun jepang yang memiliki hasil yang tinggi, perlu diberikan perlakuan tanpa pemangkasan pucuk pada batang utama dan pemangkasan pucuk seluruh cabang lateral, serta perlakuan pemangkasan pucuk pada batang utama dan pemangkasan pucuk 5 cabang lateral.

\section{DAFTAR PUSTAKA}

Badan Pusat Statistik. 2016. Produksi jenis sayuran. Jakarta.

Cahyono, B. 2003. Teknik dan Strategi Budidaya Mentimun. Yayasan Pustaka Mentimun. Yayasan Pustaka Nusantara. Yogyakarta.

Dewani, M. 2000. Pengaruh Pemangkasan terhadap Pertumbuhan dan Hasil Tanaman Kacang Hijau (Vigna radiate L) Varietas Walet dan Wongsorejo. Jumal Agrista. (12):18-23.

.Gomez, A, K dan Arturo A Gomez. 2007. Prosedur Statistik untuk Penelitian Pertanian (Edisi 2). UI Press.

Januwati, M. Joko P. dan Ngadimin. 1996. Pengaruh Pemangkasan Terhadap Pertumbuhan dan Produksi Terna Tanaman Sambiloto. Warta Tumbuhan Obat Indonesia. Balai Penelitian Tanaman Obat dan Rempah. Bogor.

Rukmana, R. 1994. Budidaya Mentimun. Kanisius. Yogyakarta.

Rosliani, R. 2013. Budidaya Mentimun. Balai Penelitian Tanaman Sayuran. Lembang.

Yadi, S. La Karimuna, dan L, Sabaruddin. 2012. Pengaruh Pemangkasan dan Pemberian Pupuk Organik Terhadap Produksi Tanaman Mentimun (Cucucmis sativus L). Berkala Penelitian Agronomi 1 (2):107-114. Unhalu.

Pengaruh Pemangkasan Pucuk terhadap

Pertumbuhan dan Hasil Tanaman 